\title{
Development Peculiarities of Bean Anthracnose and Protective Measures
}

\author{
G.V. Avagyan \\ Armenian National Agrarian University \\ gayaneavagyan@yahoo.com
}

\section{ARTICLE INFO}

\section{Keywords:}

bean,

anthracnose,

dynamics of development,

preventive measures,

fungicide

\begin{abstract}
A B S T RACT
The life cycle of Colletotrichum lindemuthianum fungus, susceptibility of Armenian bean varieties to anthracnose disease, as well as its development dynamics have been investigated in conditions of Lor community in Aremenia.

Preventive measures have reduced the winter stock of pathogen infection and intensity of the disease development, while double application of Quadris and Revus Top fungicides during the vegetation period suppressed the development of anthracnose by $86.3-88.6 \%$ and 91.6-92.4\%, respectively, as compared to the recorded indices in the control variant.

Thus, the recommended fungicides can be used alternately to combat bean anthracnose.
\end{abstract}

\section{Introduction}

The common dry bean or Phaseolus vulgaris L., is the most important legume crop for direct consumption in the world. Among major food crops, it has one of the highest levels of variation in growth habit, seed characteristics (size, shape, colour), maturity and adaptation. Beans are nearly "perfect" food. Being nutritionally rich, they are also a good source of protein, folic acid, dietary fibre and complex carbohydrates (http://www.fao.org).

Diseases are the main reason of bean yield decline. Anthracnose is one of the most dangerous bean diseases in the world and can result in up to $100 \%$ crop loss (Silva, et al., 2007). Anthracnose mostly infects common beans (P. vulgaris), however, other legume varieties can also be infected (http://vegetablemdonline.ppath.cornell.edu/).

\section{Materials and methods}

Field surveys on bean anthracnose were conducted in conditions of Lor community, at the RA Sisian province, during 2017-2019. Bean infectivity with anthracnose (P), as well as the degree of disease development (R) was assessed according to the common methods accepted in plant pathology (Dementyeva, 1985, Chumakov, et al., 1974). 
The intensity of the anthracnose infection of plant leaves and pods was assessed with a 5-point scale:

0 point - no infection,

1 point - up to $10 \%$ of the leaf and beans/pods surface is infected,

2 points $-10.1 \%-25 \%$ of the leaf and beans/pods surface is infected,

3 points $-25.1 \%-50 \%$ of the leaf and beans/pods surface is infected,

4 points - more than $50.1 \%$ of the leaf and beans/pods surface is infected.

The disease rate $(\mathrm{P})$, as well as the biological efficacy of the fungicides applied during the experiments were calculated through the respective formulae (Dementyeva, 1985).

\section{Results and discussions}

The causative agent of bean anthracnose is the fungus Colletotrichum lindemuthianum (Sacc. \& Magnus) Briosi \& Cavara (https://www.mycobank.org/). Bean seedlings grown from seeds infected with anthracnose often have dark brown to black sunken lesions on the cotyledons and stems. Diseased areas may girdle the stem and kill the seedling (http://vegetablemdonline.ppath.cornell.edu/). Under moist conditions, small, pink masses of spores are produced in the lesions. Spores produced on cotyledon and stem lesions may spread to the leaves. Symptoms generally occur on the underside of the leaves as linear, dark brick-red to black lesions on the leaf veins (Figure). As the disease progresses, the discoloration appears on the upper leaf surface.

The most striking symptoms develop on the pods. Small, reddish brown to black blemishes and distinct circular, reddish brown lesions are typical symptoms of bean anthracnose (Figure). Mature lesions are surrounded by a circular, reddish brown to black border with a grayish black interior (http://vegetablemdonline.ppath.cornell.edu/).

During moist periods, the interior of the lesion may exude pink masses of asexual sporulation - acervuli with spores. Severely infected pods may shrivel, and the seeds they carry are usually infected (Avagyan, 2006).

C. lindemuthianum fungus can survive for up to 5 years in infected bean pods and seeds that are air-dried and stored at $4^{0} \mathrm{C}$. Survival is drastically reduced, however, when infected materials are buried in the field and come in contact with water (http://vegetablemdonline.ppath.cornell.edu/). Overwintering of the fungus on plant residues or in the soil greatly depends on climatic conditions. Humid weather conditions with mild temperatures $\left(13-26^{\circ} \mathrm{C}\right.$ and relative humidity greater than $92 \%$, or free moisture) during vegetation period contribute to the development of anthracnose on young leaves and beans (https:// ag.umass.edu/).

Moisture is required for development, spread and germination of the spores, as well as for infection of the plant. A prolonged wet period is necessary for the fungus to establish its infection. The time from infection to visible symptoms ranges from 4 to 9 days, depending on the temperature, bean variety and age of the infected tissues (http://vegetablemdonline.ppath.cornell.edu/). The fungal spores are easily carried to healthy plants in wind-blown rain and by people and machinery moving through contaminated fields when the plants are wet, as well as by insects.

The damage caused by anthracnose to bean plants is manifested by a decrease in seed germination (up to $70 \%$ ), a change in the stems, leaves and pods, yield decrease, quality and taste of grains (Kotova and Kungurtseva, 2014).

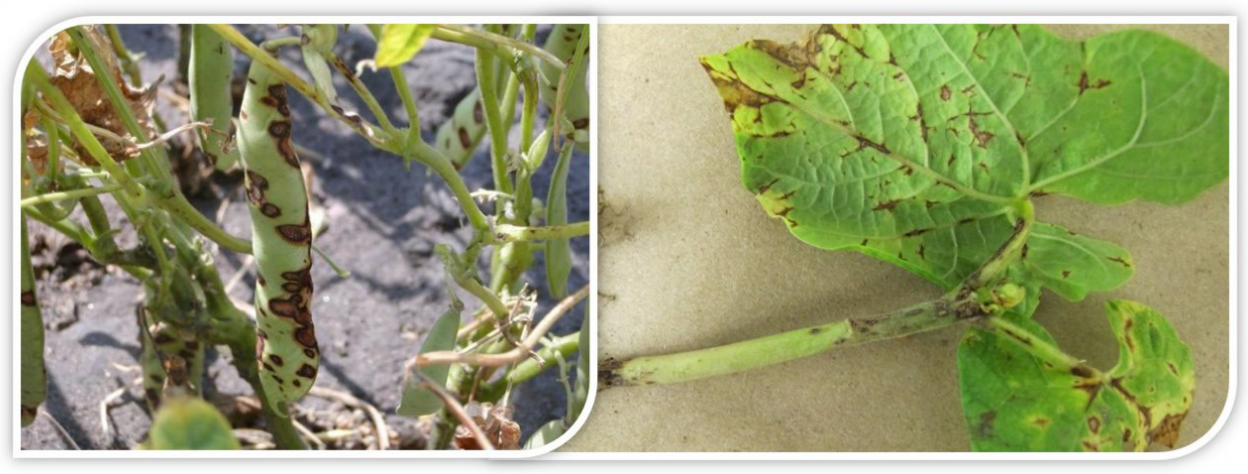

Figure. The symptoms of bean anthracnose on the pods and leaves. 


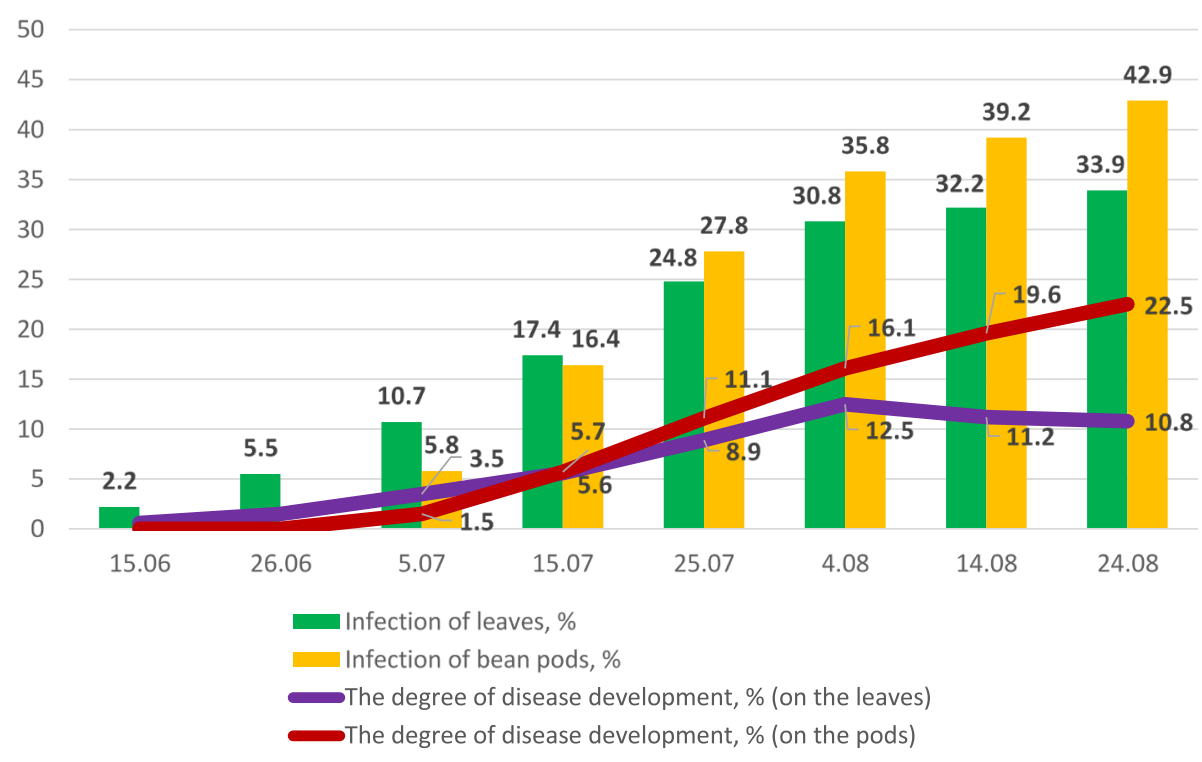

Diagram 1. Dynamics of bean anthracnose development, 2017 (composed by the author).

The pathogen of bean anthracnose may form also a sexual teleomorphic stage during life cycle (Glomerella cingulata (Stonem.) Spauld. and Schrenk. f. sp. phaseoli), however, in conditions of the Republic of Armenia, it successfully overwinters in an asexual anamorph stage on plant residues, in the soil, as well as in infected grains - in the form of mycelium. The source of the plant primary, secondary and the following infections is the asexual sporulation.

During the vegetation season of 2017 in Lor community of Sisian province, we studied the dynamics of the development for bean anthracnose on "Armenian red" variety. Calculations were conducted after the first signs of the disease appeared, with a 10-day interval (Diagram 1). First symptoms of bean anthracnose were registered in the first decade of June. During June, bean anthracnose developed slowly (Infectivity of leaves was $5.5 \%$, disease intensity 1-2 points with the average of 1.1 points, and the degree of disease development $1.5 \%$ ), but during July a rapid development of the disease was registered due to favorable weather conditions. According to the calculations made on August 4, the degree of leaf infestation with anthracnose was $30.8 \%$, the pods infestation was $35.8 \%(\mathrm{P})$, the disease intensity 1.6-1.8 points, and the degree of anthracnose development was $8.9-11.1 \%(\mathrm{R})$ for leaves and pods respectively.

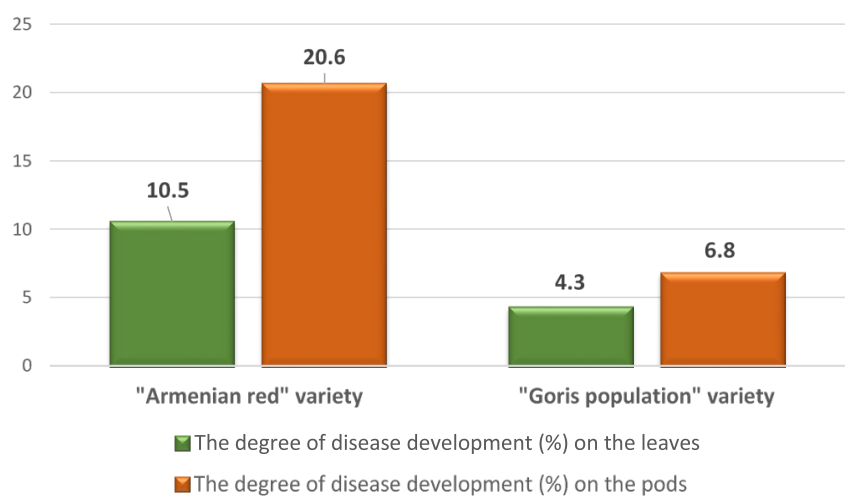

Diagram 2. Infection of local bean varieties with anthracnose (average data for 2018-2019) (composed by the author). 
A depressive development of anthracnose disease on bean leaves was recorded during August - due to "leaves aging", while the infection of bean pods continued to grow - reaching $42.9 \%$ (P for pods). In September, due to "aging of leaves and pods", a complete depression of anthracnose was recorded.

Above presented data coincide with research results of R.B. Martirosyan, according to which in Stepanavan province, Armenia, the development of bean anthracnose begins in late May - early June, the development of the disease reaches its maximum in the first decade of July and stops at the end of August, due to the full maturity of bean plant (Martirosyan, 1967).

While examining the infestation rate of local bean varieties "Armenian red" and "Goris population" with anthracnose (during 2018-2019), we found out (Diagram 2), that in case of bean cultivation without fungicide applications, the two most widely cultivated Armenian varieties have shown high to moderate sensitivity to anthracnose.

During 2018-2019, we studied also the effectiveness of fungicides applications against bean anthracnose. Experiments were carried out on the basis of the following preventive measures:

- healthy pods were harvested in the previous fall to obtain healthy seeds,

- after the harvest, all plant residues were destroyed (it is desirable to change the crop and return to the same field at least in the 3rd or 4th year, when the "self-cleaning" of the soil from pathogenic fungi took place),

- seeds were sorted before sowing: shriveled, discolored, diseased seeds were selected and removed,

- seeds were sown in a well-ventilated and well-drained area, optimal sowing density was observed,
- no plant care measures were implemented in the mornings and after precipitations, as bean anthracnose spreads more intensively in wet conditions.

During the growing seasons "Armenian red" bean plants were sprayed twice: the first application was administered at the stage of 5-6 true leaves, the second - at the beginning of the budding stage (according to the $\mathrm{BBCH}$ scale of phenological stages developed for beans, (https:// en.wikipedia.org). The experiment was conducted with the following scheme:

1. Control - without spraying,

2. Two applications were conducted with Copper oxychloride WP (active ingredient: Copper Chloride $900 \mathrm{~g} / \mathrm{kg}$, application rate $-4 \mathrm{~kg} / \mathrm{ha})$,

3. Two applications were administered with Antracol WP (active ingredient: Propineb - $700 \mathrm{~g} / \mathrm{kg}$, application rate $-2.5 \mathrm{~kg} / \mathrm{ha})$,

4. Two applications were realized with Quadris SC (active ingredient: Azoxystrobin - $250 \mathrm{~g} / \mathrm{l}$, application rate $0.6 \mathrm{l} / \mathrm{ha})$,

5. Two applications were conducted with Revus Top SC (active ingredients: Difenoconazole - $250 \mathrm{~g} / 1$ and Mandipropamid - $250 \mathrm{~g} / \mathrm{l}$, application rate $-0.5 \mathrm{l} / \mathrm{ha}$ ).

Fungicides weren't applied after flowering due to the risk of pesticide residues in the pods.

The selection of pesticides was based on the preparations against bean anthracnose recommended in various literature sources (Kotova and Kungurtseva, 2014; Booklet, Revus Top Fungicide. Washington, D.C. 20460; Bayer Crop Science. Official Website of Iraq; Quadris Anthracnose Protection for Dry Beans; Characterization of Anthracnose Resistance in Common Bean, 2015). The

Table. Biological efficiency of fungicides against bean anthracnose (Lor community, 2018-2019)*

\begin{tabular}{|c|c|c|c|c|}
\hline \multirow{2}{*}{ Experimental versions } & \multicolumn{2}{|c|}{$\begin{array}{c}\text { Degree of disease development (R), } \\
\%\end{array}$} & \multicolumn{2}{|c|}{$\begin{array}{c}\text { Biological efficiency, } \\
\%\end{array}$} \\
\hline & on the leaves & on the pods & on the leaves & on the pods \\
\hline Control & 10.5 & 22.6 & - & - \\
\hline Copper Oxychloride 4 kg/ha x 2 & 3.2 & 7.2 & 69.5 & 68.1 \\
\hline Antracol $2.5 \mathrm{~kg} / \mathrm{ha} \times 2$ & 1.5 & 3.4 & 85.7 & 84.9 \\
\hline Quadris 0.6 1/ha x 2 & 1.2 & 3.1 & 88.6 & 86.3 \\
\hline Revus Top 0.5 1/ha x 2 & 0.8 & 1.9 & 92.4 & 91.6 \\
\hline
\end{tabular}


Pesticide Handbook published by the the Food Safety Inspectorate of the Republic of Armenia does not include fungicides or seed disinfectants against bean anthracnose (https://snund.am).

The summary results of pre-harvest calculations for 2018-2019 are presented in Table. Double applications of fungicides Copper Oxychloride and Antracol during vegetation period have reduced the development of bean anthracnose by 69.5-68.1\% (for leaves and pods) and 84.9-85.7 \% (for leaves and pods), respectively. The two sprayings with fungicides Quadris and Revus Top during vegetation period have significantly suppressed the development of anthracnose, providing 86.3-88.6\% (for leaves and pods) and 91.6-92.4\% (for leaves and pods) biological efficiency, respectively. Fungicides with higher biological efficiency - Quadris (0.6 1/ha) and Revus Top (0.5 1/ha), are recommended to be used alternately in the fight against bean anthracnose.

\section{Conclusion}

Based on the above stated reserch results the following conclusions can be drawn:

1. The pathogenic fungi of bean anthracnose overwinters in the asexual anamorph stage - on plant residues, in the soil, as well as in infected grains - in a form of mycelium. The source of the plant primary, secondary and the following infections is the asexual sporulation.

2.In Lor community of the Sisian province, the development of bean anthracnose mainly starts at the beginning of June; at first it develops slowly, then, in July, there is a rapid and intense development of the disease. A depressive development of anthracnose disease was recorded on bean leaves during August and on pods - in September, due to "aging of leaves and pods".

3. Out of the two studied local bean varieties, the higher susceptibility to anthracnose was recorded in the variety "Armenian red", comparatively lower - in the variety "Goris population". Thus, in case of bean cultivation without fungicides, the two most widely cultivated Armenian varieties have shown high to moderate sensitivity to anthracnose.

4. Preventive measures can play an important role in the fight against bean anthracnose: selection of seeds from healthy pods, removal of plant residues, seed sorting, observance of the optimal sowing density, plant care only in dry weather. These measures reduce both the overwintering stock of anthracnose infection and the intensity of disease development during the vegetation period.

5. Two-time spraying (the first application was done at the stage of 5-6 true leaves, the second - at the beginning of the budding stage) of bean plants against anthracnose with different fungicides (Copper Oxychloride $4 \mathrm{~kg} / \mathrm{ha}$, Antracol- $2.5 \mathrm{~kg} / \mathrm{ha}$, Quadris- 0.6 1/ha, Revus Top - 0.5 1/ha) provided high biological efficiency on the background of preventive measures. Fungicides with higher biological effeciency - Quadris (0.6 1/ha) and Revus Top $(0.51 / \mathrm{ha})$, are recommended to be used alternately in the fight against bean anthracnose to avoid resistance development.

\section{References}

1. Avagyan, G.V. (2006). Practical Guide of Agricultural PlantPathology: Yerevan, ANAU,-142 p. (in Armenian).

2. Bayer Crop Science. Official Website of Iraq: https://www. iraq.cropscience.bayer.com/en/Products/Fungicides/ Antracol-70-WP.aspx (accessed on 03.02.2021).

3. Characterization of Anthracnose Resistance in Common Bean. Guelph, Ontario, Canada, 2015: https://atrium. lib.uoguelph.ca/xmlui/bitstream/handle/10214/9287/ vazin maryam 201508 MSc.pdf; sequence $=3$ (accessed on 03.02.2021).

4. Chumakov, A.K., Minkevich, I.I., Vlasov, Yu.I., Gavrilova, E.A. (1974). Basic Methods of Phytopathological Research. Moscow: Kolos, - 191 p. (in Russian).

5. Dementyeva, M.I. (1985). Phytopathology. Moscow, Agropromizdat, - 397 p.

6. Department of PlantPathology, New York State Agricultural Experiment Station, Geneva Cornell University: http:// vegetablemdonline.ppath.cornell.edu/factsheets/Beans Anthracnose.htm (accessed on 25.11.2020).

7. https://www.mycobank.org/BioloMICS.aspx?TableK $\underline{e y}=14682616000000067 \&$ Rec $=419190 \&$ Fields $=$ All (accessed on 17.09.2020).

8. Kotova, V.V., Kungurtseva, O.V. (2014). Anthracnose of Agricultural Plants. Plant Protection News, Supplements. Issue 11, - St. Petersburg, - 133 p. http:// vizrspb.ru/assets/docs/vestnik/sup/s11.pdf (in Russian) (accessed on 03.02.2021).

9. Martirosyan, R.B. (1967). Development of Bean Anthracnose in Conditions of Stepanavan Province, Armenian SSR // Biological Journal of Armenia, XX - N 3, - pp. 68-74 (in Russian). 
10. Official Website of the Company Imarket Agro: https:// imarketsemyan.com.ua/products/sistema-zashityfasoli-ot-imarket-agro (accessed on 03.04.2020).

11. Pesticide Handbook on Chemical and Biological Plants Protection Means Permitted For Use in the Republic of Armenia. Published by the the Food Safety Inspection Body of the Republic of Armenia: https:// snund.am/wp-content/uploads/2015/10/texekatu2015. pdf (accessed on 03.02.2021).

12. PHASEOLUS BEAN: Post-Harvest Operations. Booklet: http://www.fao.org/3/a-av015e.pdf (accessed on 22.09.2020).

13. Quadris - Anthracnose Protection for Dry Beans: https://www.syngentacropprotection.com/assets/ assetlibrary/canada quadris drybean.pdf (accessed on 03.02.2021).

14. Silva, K.J.D., Souza, E.A., Ishikawa, F.H. (2007). Characterization of Colletotrichum Lindemuthianum
Isolates from the State of Minas Gerais, Brazil // J. Phytopathol. 155, - pp. 241-247.

15. Tamil Nadu Agricultural University (TNAU) Madras - College of Agricultural Technologies, Bean Anthracnose - Educational Materials: https://www. slideshare.net/MuthuKutti2/bean-anthracnose (accessed on 15.09.2020).

16. United States Environmental Protection Agency. Booklet, Revus Top Fungicide. Washington, D.C. 20460: https://www3.epa.gov/pesticides/chem_search/ ppls/000100-01278-20140501.pdf (accessed on 03.02.2021)

17. University of Massachusetts Amherst., Center for Agriculture, Food and the Environment: https:// ag.umass.edu/vegetable/fact-sheets/bean-anthracnose (accessed on 22.09.2020).

18. Wiki Encyclopedia: https://en.wikipedia.org/wiki/ BBCH-scale_(bean) (accessed on 03.02.2020). 